\title{
Metabolic Syndrome Components and Nutritional Status among Hypertensive Outpatiens at Dr. Hasan Sadikin General Hospital Bandung
}

\author{
Lira Mirandus, ${ }^{1}$ Hikmat Permana, ${ }^{2}$ Siti Nur Fatimah ${ }^{3}$ \\ ${ }^{1}$ Faculty of Medicine Universitas Padjadjaran, ${ }^{2}$ Department of Internal Medicine Faculty of \\ Medicine Universitas Padjadjaran/Dr. Hasan Sadikin General Hospital Bandung, ${ }^{3}$ Department of \\ Medical Nutrition Faculty of Medicine, Universitas Padjadjaran
}

\begin{abstract}
Background: Metabolic syndrome and overnutritional status (overweight and obesity) are examples of determinants that can give rise to hypertension, so the three diseases are correlated with each other. This study aimed to reveal metabolic syndrome components and nutritional status among hypertensive outpatients.

Methods: This study involved 44 hypertensive outpatients who visited the Nephrology and Hypertension Clinic of Dr. Hasan Sadikin Hospital, Bandung in September to October 2013. Anthropometric and blood pressure measurements, anamnesis, and medical record data collection were carried out to describe the patient's metabolic syndrome components by using International Diabetes Federation criteria on South Asian people and nutritional status by WHO classification in Asian people.

Results: Among respondents, 25 (57\%) had abdominal obesity, 14 (32\%) had hypertrygliceridemias, 14 (32\%) had low HDL cholestrol, 19 (43\%) were taking lipid-lowering medications, 20 (45\%) had high level of fasting blood glucose, $21(48 \%)$ had been diagnosed as mellitus type 2, 15 (34\%) had high blood pressure, $40(91 \%)$ were taking antihypertensive medications, 19 (43\%) had metabolic syndrome, and 31 (70\%) were overweight or obese.

Conclusions: Less than a half of the respondents meet the metabolic syndrome criteria and over two third of them are at overnutrition state (overweight or obesity). [AMJ.2016;3(3):477-81]
\end{abstract}

Keywords: Hypertension, metabolic syndrome, nutritional status

\section{Introduction}

In recent years, the prevalence of noncommunicable diseases (NCDs) in world population has grown rapidly. The NCDs and all of its negative impacts were responsible for almost two third of the world's 57 million death in 2008, yet more than a half ofthose occurred in low and middle income countries, including Indonesia. ${ }^{1}$

Hypertension, metabolic syndrome, overnutritional status (overweight and obesity) are NCDs. ${ }^{2}$ Hypertension is a condition where arterial blood pressure rises abnormally. ${ }^{5}$ Metabolic syndrome is a cluster of some metabolic abnormalities that consists of diabetes melitus or increased fasting plasma glucose, abdominal obesity, high LDL cholesterol, low HDL cholesterol and high blood pressure. ${ }^{6}$ According to theInternational Diabetes Federation (IDF), for a person to be defined with metabolic syndrome they must have central obesity plus any criteria of four following factors: raised tryglicerides $(\geq 150$ $\mathrm{mg} / \mathrm{dl})$, reduced HDL cholesterol $(<40 \mathrm{mg} /$ $\mathrm{dl}$ in males and $<50 \mathrm{mg} / \mathrm{dl}$ in females), raised blood pressures (systolic BP $\geq 130 \mathrm{mmHg}$ or diastolic $\mathrm{BP} \geq 85 \mathrm{mmHg}$ or with treatment of previously diagnosed hypertension), and high fasting plasma glucose $(\geq 100 \mathrm{mg} / \mathrm{dl}$ or previously diagnosed diabetes mellitus). ${ }^{6}$ Nutritional status is a stratification reflecting whether physiologic needs of nutritions are being met. It can be assessed by some ways, one of them is body mass index (BMI) that furtherly divided into four cathegories, which two of them, overweight and obesity, reflects overnutritional status. ${ }^{7}$ Metabolic syndrome can give rise to hypertension, as the presence

Correspondence: Lira Mirandus, Faculty of Medicine, Universitas Padjadjaran, Jalan Raya Bandung-Sumedang Km.21, Jatinangor, Sumedang, Indonesia, Phone: +628568517229 Email: liramirandus@gmail.com 
of insulin resistance activate renin angiotensin aldosteron system and symphatetic nervous system. ${ }^{5}$ Through insulin resistance and proliferation of glomerular capillary endothelium, overnutritional status can also cause hypertension. ${ }^{5}$ Those facts make the relationship of the three diseases very clear, yet there is no study that describes how metabolic syndrome components and overnutrition exist in hypertensive people, at least in West Java, Indonesia's most populous province. The aim of this study was to describe the metabolic syndrome components and nutritional status among hypertensive patients.

\section{Methods}

This cross-sectional study was carried out at theNephrology and Hypertension Clinic, Dr. Hasan Sadikin General Hospital Bandung, in September-October 2013. It involved previously-diagnosedhypertensiveoutpatients who visited the clinic, regardless whether they were new or follow up patients. The aim and the way this study would be conducted had been approved by Dr. Hasan Sadikin General Hospital's Ethical Committee. This study used non probability consecutive sampling as its data collection method. The amount of minimal samples was determined by using the minimal sample formula on cathegorical descriptive variables with deviation standard alpha of 1.96 of $95 \%$ confidence interval, 10\% precision (d), and presumed proportion of 0.5 that was calculated as 43 samples.

Hypertensive outpatients were evaluated to define whether they fulfilled IDF metabolic syndrome criteria on South Asian people, and then the measurement of body height and weight were performed to define nutritional status based on their BMI for Asian people. ${ }^{8}$ The IDF defines metabolic syndrome as the presence of abdominal obesity (waist circumference $\geq 90 \mathrm{~cm}$ for South Asian men and $\geq 80 \mathrm{~cm}$ for South Asian women), plus at least two of these following factors: raised tryglicerides $(\geq 150 \mathrm{mg} / \mathrm{dl})$, reduced $\mathrm{HDL}$ cholesterol $(<40 \mathrm{mg} / \mathrm{dl}$ in males and $<50 \mathrm{mg}$ / $\mathrm{dl}$ in females), raised blood pressures (systolic $\mathrm{BP} \geq 130 \mathrm{mmHg}$ or diastolic $\mathrm{BP} \geq 85 \mathrm{mmHg}$ or with treatment of previously diagnosed hypertension), and high fasting plasma glucose ( $\geq 100 \mathrm{mg} / \mathrm{dl}$ or previously diagnosed diabetes mellitus). ${ }^{6}$ The nutritional status was classiffied into four categories according to World Health Organization (WHO) classification of body mass index in Asian people thus underweight for BMI $<18.5 \mathrm{~kg} / \mathrm{m}^{2}$, normal for BMI $18.5-$ $22.9 \mathrm{~kg} / \mathrm{m}^{2}$, overweight for BMI $23-24.9 \mathrm{~kg} /$ $\mathrm{m} 2$, and obese for BMI $\geq 25 \mathrm{~kg} / \mathrm{m}^{2}{ }^{2}{ }^{8}$

The patients were included in this study if they brought laboratory results paper of HDL cholesterol, tryglicerides, and fasting plasma glucose for follow up purpose, or intended to perform such tests by instruction of the clinic's doctor in charge. Exclusion criteria of this study were the patients who refused to get involved, the patients with noncomplete laboratory medical records, and the patients with vertebral abnormalities so the measurement of body height could not be performed. It was decided that laboratory data had been performed over two months before patient's admission to the clinic, were also excluded.

Furthermore, blood pressure, waist circumference, body weight and height measurements were carried out directly to the patients. Anamnesis was performed to collect the patient's name, age, previous history of type 2 diabetes melitus, medications, and medical record numbers. For the patients who brought the laboratory test results paper, the data of HDL cholesterol, triglycerides, and fasting plasma glucose could also be performed at the clinic; for the patients who did not have them, those data were taken at the Hospital's Clinical Pathology Department several weeks following the primary data collection. The previous history of type 2 diabetes melitus and medications were rechecked by data from the Outpatient Medical Record Department. However, 3 diabetes melitus history data were not successfully rechecked by medical record data because those were not available.

\section{Results}

There were 69 hypertensive outpatients visiting the clinic included in this study, however only 44 of them who were free from the exclusive criteria andwhose data would be analized. The number of both male and female subjects were 22 respectively, or with male:female ratio of 1:1 (Table 1). The 6066 age group was the largest group in total subjects and both sexes. Male patients were relatively older than female patients, which was reflected by their means and median of age.

Moreover, abdominal obesity was present in the majority of subjects. There were almost a third of the whole subjects who had hypertriglyceridemias and low HDL 
Lira Mirandus, Hikmat Permana, Siti Nur Fatimah: Metabolic Syndrome Components and Nutritional Status 479 among Hypertensive Outpatiens at Dr. Hasan Sadikin General Hospital Bandung

Table 1 General Characteristics of Subjects

\begin{tabular}{|c|c|c|c|}
\hline Features & Total $(n=44)$ & Male $(n=22)$ & Female $(n=22)$ \\
\hline \multicolumn{4}{|l|}{ Age (years old) } \\
\hline $39-45$ & $1(2 \%)$ & $1(5 \%)$ & $0(0 \%)$ \\
\hline $46-52$ & $4(9 \%)$ & $2(9 \%)$ & $2(9 \%)$ \\
\hline $53-59$ & $11(25 \%)$ & $4(18 \%)$ & $7(32 \%)$ \\
\hline $60-66$ & $19(43 \%)$ & $11(50 \%)$ & $8(36 \%)$ \\
\hline $67-73$ & $6(14 \%)$ & $2(9 \%)$ & $4(18 \%)$ \\
\hline $74-80$ & $2(5 \%)$ & $1(5 \%)$ & $1(5 \%)$ \\
\hline $81-87$ & $1(2 \%)$ & $1(5 \%)$ & $0(0 \%)$ \\
\hline \multicolumn{4}{|l|}{ Patient's Status } \\
\hline New & $1(2 \%)$ & $1(5 \%)$ & $0(0 \%)$ \\
\hline Follow up & 43 (98\%) & $21(95 \%)$ & $22(100 \%)$ \\
\hline
\end{tabular}

cholesterol level. High fasting plasma glucose level existed in slightly less than a half of the whole subjects, as well as the amount of subjects who were previously diagnosed as type 2 diabetes mellitus. There were around a third of the whole subjetcs classified as having uncontrolled high blood pressure. Nine out of ten hypertensive subjects were receiving antihypertensive medications, compared to only four of ten who were receiving lipidlowering medications. The prevalence of metabolic syndrome according to IDF criteria was $43 \%$ of the total subjects, with the majority of female subjects categorized as metabolic syndrome compared to less than a third of male subjects.

Seventy per cent of the subject was classified as overnutrition (overweight and obese) according to the WHO BMI Criteria for Asian people. ${ }^{8}$ Overnutritional status was also present in majority of both male and female subjects, both $86 \%$ and $54 \%$ respectively (Table 3).

\section{Discussion}

More than half of thehypertensive patients included in this study were aged above 60

Table 2 IDF Metabolic Syndrome Components among Hypertensive Outpatients

\begin{tabular}{lccc}
\hline \multicolumn{1}{c}{ Features } & $\begin{array}{c}\text { Total } \\
(\mathbf{n = 4 4 )}\end{array}$ & $\begin{array}{c}\text { Male } \\
(\mathbf{n = 2 2})\end{array}$ & $\begin{array}{c}\text { Female } \\
\text { (n=22) }\end{array}$ \\
\hline $\begin{array}{l}\text { Waist Circumference } \geq 90 \mathrm{~cm} \text { for male and } \\
\geq 80 \mathrm{~cm} \text { for female }\end{array}$ & $25(57 \%)$ & $8(36 \%)$ & $17(77 \%)$ \\
Triglycerides $\geq 150 \mathrm{mg} / \mathrm{dl}$ & $14(32 \%)$ & $9(41 \%)$ & $5(23 \%)$ \\
$\begin{array}{l}\text { HDL Cholesterol }<40 \mathrm{mg} / \mathrm{dl} \text { for male and } \\
<50 \mathrm{mg} / \mathrm{dl} \text { for female }\end{array}$ & $14(32 \%)$ & $6(27 \%)$ & $8(36 \%)$ \\
With Lipid-Lowering Medications & $19(43 \%)$ & $10(53 \%)$ & $9(47 \%)$ \\
Fasting plasma glucose $>100 \mathrm{mg} / \mathrm{dl}$ & $20(45 \%)$ & $14(64 \%)$ & $6(27 \%)$ \\
$\begin{array}{l}\text { With Previous Diagnosis of Type 2 Diabetes } \\
\text { Mellitus }\end{array}$ & $21(48 \%)$ & $14(64 \%)$ & $7(32 \%)$ \\
Blood Pressure $\geq 130 / 85$ mmHg & $15(34 \%)$ & $9(41 \%)$ & $6(27 \%)$ \\
With Antihypertensive medications & $40(91 \%)$ & $18(82 \%)$ & $22(100 \%)$ \\
Fulfill IDF Criteria on Metabolic Syndrome & $19(43 \%)$ & $7(32 \%)$ & $12(55 \%)$ \\
\hline
\end{tabular}

Note : IDF=International Diabetes Federation, HDL=High Density Lipoprotein 
Table 3 Nutritional Status among Hypertensive Outpatients

\begin{tabular}{lccc}
\hline \multicolumn{1}{c}{ BMI Classification } & $\begin{array}{c}\text { Results in Total } \\
(\mathbf{n = 4 4 )}\end{array}$ & $\begin{array}{c}\text { Results in Male } \\
(\mathbf{n = 2 2})\end{array}$ & $\begin{array}{c}\text { Results in Female } \\
(\mathbf{n = 2 2})\end{array}$ \\
\hline Underweight & $1(2 \%)$ & $0(0 \%)$ & $1(5 \%)$ \\
Normal & $12(27 \%)$ & $3(14 \%)$ & $9(41 \%)$ \\
Overweight & $16(36 \%)$ & $10(45 \%)$ & $6(27 \%)$ \\
Obese & $15(34 \%)$ & $9(41 \%)$ & $6(27 \%)$ \\
\hline
\end{tabular}

Note : BMI=Body Mass Index

years, both in male and female sex groups. That characteristic was considered relatively to be same with two previous studies conducted in Taiwan. ${ }^{9,10}$ The predominance of follow-up patients group over new patients might be due to the function of the hospital as a referral destination from the primary health care which made thefirst diagnosis and initial management before referring.

This study revealed that abdominal obesity was present in the majority of hypertensive outpatients. In spite of its different amount of prevalence (62.2\%), a study published by Hsu et al. ${ }^{9}$ in 2005 has also shown that phenomenon. Both prevalences revealed in this study and in the study of Hsu et al. ${ }^{9}$ were higher than thegeneral population according to Indonesia's National Basic Health Research 2007 which reported only $18.8 \%{ }^{11}$

There were almost similar prevalence of hypertrygliceridemia according to this study and the different studies established by $\mathrm{Su}$ et al. $^{10}$ and Hsu et al. ${ }^{9}$ as they reported that high plasma triglyceride level is present in $34.74 \%$ and $40.50 \%$ of hypertensive patients. Nonetheless, Su et al. ${ }^{10}$ and $\mathrm{Hsu}$ et al. ${ }^{9}$ both have shown that low HDL cholesterol exist in $69.7 \%$ and $78.2 \%$ of the same subjects, which was quite different with this study. Those variations could possibly be caused by differences in the amount of subjets who were receiving lipid-lowering drug administrations, and how data were collected. Su et al. ${ }^{10}$ and Hsu et al. ${ }^{9}$ carried out simultaneous blood sample collection to their subjects and used standardized laboratory examination method instead of taking secondary data from the subjects' medical record with varying time. In this study, $43 \%$ of the subjects were receiving lipid-lowering medications. That results could possibly be influenced by a limitation such as 3 unrechecked medication history of anamnesis data because of the medical record incompleteness.

Furthermore, Su et al..$^{10}$ reported that high fasting plasma glucose (above $100 \mathrm{mg} / \mathrm{dl}$ ) is present in almost two third of hypertensive patients, which wasquite varied from less than a half according to this study. However, that study only involved hypertensive outpatients from the Cardiology and Neurology Department without those from theEndocrinology Department, as opposed to this study which included patients from the two departments, which could influence the results, since the Endocrinology Department had significant numbers of diabetic patients with uncontrolled fasting plasma glucose.

Moreover, Hsu et al. ${ }^{9}$ stated that $30.11 \%$ of hypertensive outpatients were previously diagnosed as having type 2 diabetes mellitus, lower than what this study showed. Having explained before, that the study have not involved patients in the Departement of Endocrinology, hence it could lower the number of hypertensive subjects.

There were about one third of hypertensive outpatients who remained having high blood pressure, although the fact was $91 \%$ of them were receiving antihypertensive medications. The effectivity of such medication in reducing blood pressure depends on thepatient's obedience, the patient's condition, and medication completeness, while the subjects' blood pressure were measured.

According to this study, there was $43 \%$ of hypertensive outpatients who fulfilled the IDF criteria on metabolic syndrome. A previous study revealed that metabolic syndrome (using IDF criteria) is present in $54.67 \%$ of hypertensive outpatients, which was slightly different with this study. ${ }^{10}$ Both two studies established higher prevalences than a study that used the same criteria and was conducted by Zainuddin et al. ${ }^{13}$ in the Malaysian general population which was $33.33 \%$. A research established by Kelishadi et al. ${ }^{14}$ from Isfahan, Iran, concluded that the prevalence of metabolic syndrome is rather higher in hypertensive than in normotensive population. It strongly reflects that metabolic syndrome tends to be more prevalent in 
hypertensive population than in the general one. Rahajeng and Tuminah ${ }^{3}$ reported that there are about $11.2 \%$ and $14.7 \%$ classified as overweight or obese among hypertensive population, which is much lower than this study revealed. Their study involved over a hundred thousand rural and urban subjects taken from 33 provinces across Indonesia which were very different from this study's mostly urban and local subjects. The same study also revealed that overnutrition is more prevalent in hypertensive than in general population.

As a conclusion, the metabolic syndrome components according to IDF among hypertensive outpatients are more than a half have abdominal obesity, almost a third have hypertriglyceridemia and low plasma HDL cholesterol level, almost a half have high fasting blood glucose level, almost two third have uncontrolled high blood pressure. Whereas, patients with antihypertensive medications are much higher than who are not with 9:1 ratio, and lipid-lowering medicated patients and patients with previous history of type 2 diabetes mellitus are less than a half. The prevalence of metabolic syndrome among hypertensive outpatients is $43 \%$. There are more than $70 \%$ of hypertensive outpatients classified as overweight or obese.

\section{References}

1. Alwan A, Armstrong T, Bettcher D, Branca F, Chissholm D, Ezzati M, et al. Global Status Report of Non Communicable Diseases 2010. In: WHO, editor. Geneva: World Health Organization; 2011.

2. Soewondo P, Purnamasari D, Oemardi M, Waspadji S, Soegondo S. Prevalence of metabolic syndrome using NCEP/ ATP III criteria in Jakarta, Indonesia : the Jakarta primary non-communicable disease risk factors surveillance 2006. Acta Med Indones-Indones J Intern Med. 2010;42(4):199-203.

3. Rahajeng E, Tuminah S. Prevalensi hipertensidan determinannyadi Indonesia. Maj Kedokt Indon. 2009;59(12):580-587.

4. Pusat Komunikasi Publik Kementerian Kesehatan Republik Indonesia. Penyakit Tidak Menular (PTM) Penyebab Kematian Terbanyak di Indonesia. Jakarta: Kementerian Kesehatan RI; 2011; [cited 2 December 2012] Available from: http://www.depkes.go.id/index.php/ berita/press-release/1637-penyakit- tidak-menular-ptm-penyebab-kematianterbanyak-di-indonesia.html.

5. Kotchen TA. Hypertensive Vascular Disease. In: Longo DL, Kasper DL, Jameson JL, Fauci AS, Hauser SL, Loscalzo J, editors. Harrison's Principle of Internal Medicine. 18th ed. New York: McGraw-Hill; 2012. p. 2042-59.

6. Alberti SG, Zimmet P, Shaw J, Grundy SM. The IDF consensus worldwide definition of the metabolic syndrome. In: International Diabetes Federation, editor. Brussels: International Diabetes Federation; 2006. p. $1-23$.

7. Hammond K. Assessment: dietary and clinical data In: Mahan LK, Escott-Stump S, editors. Krause's Food \& Nutrition Therapy. 12th ed. St.Louis: Saunders Elsevier; 2008. p. 383-410.

8. WHO Expert Consultation. Appropriate body mass index for Asian populations and its implications for policy and intervention strategies. The Lancet. 2004;363:157-163.

9. Hsu CN, Chen YC, Wang TD. Prevalence and Characteristics of the Metabolic Syndrome in Chinese Hypertensive Patients : A Hospital-Based Observation. Acta Cardiol Sin. 2005;21:89-97.

10. Su CH, Fang CY, Chen JS, Po HL, Chou LP, Chiang CY, et al. Prevalence of Metabolic Syndrome and Its Relationship with Cardiovascular Disease among Hypertensive Patients 55-80 Years of Age. Acta Cardiol Sin. 2011;27:229-237.

11. Departemen Kesehatan Republik Indonesia. Prevalensi obesitas sentral pada orang dewasa diatas 15 tahun menurut provinsi. In: Riset Kesehatan Dasar 2007, editor. Jakarta: Departemen Kesehatan Republik Indonesia; 2007.

12. Departemen Kesehatan Republik Indonesia. Prevalensi asma, penyakit jantung, diabetes, dan tumor menurut provinsi. In: Riset Kesehatan Dasar 2007, editor. Jakarta: Departemen Kesehatan Republik Indonesia; 2007.

13. Zainuddin LRM, Isa N, Muda WMW, Mohamed HJ. The Prevalence of metabolic syndrome according to various definitions and hypertriglyceridemicwaist in Malaysian adults. Int J Prev Med. 2011;2(4):229-37.

14. Lioudaki E, Vrentzos GE, Mavrogeni $\mathrm{H}$, Zeniodi M-H, Ganatokis ES, Mikhalidis DP, et al. Prevalence of metabolic syndrome according to different definitions in a hypertensive population. Angology. 2011;63(1):39-47. 